\section{Germany in perspective}

SIR - Your pen-lashing of Mr Nicholas Ridley (Nature 346, 203; 1990) was adequately rebutted by W. Frank Harris and J. F. Mackenzie (Nature 347, 510; 1990).

Whether the fears and misgivings of German characteristics are justified or not is beside the point. The point is that fears about the long-term fall-out from German reunification are real and are by no means felt only in Britain. As a cardiologist, I have no expertise in genetics, but I do know that recent German policy on 'eugenics' killed my parents in the gas chambers.

I have been prompted to react only after reading the self-justification of German physician-scientist E. Guthy (Nature 348, 670 1990). According to Guthy's criteria, I am qualified to articulate my ideas of "national or racial characteristics" having been exposed to a foreign culture and country from 10 May 1940 to 5 April 1945. That was quite an exposure. During those five years, Dutch culture vanished, all traffic signs and death warrants were written in German, 100,000 Jews were ausradiert, innocent people were executed without trial, our country was plundered and its infrastructure destroyed; and everything, indeed, done with a "striving for perfection and overdoing things" unparalleled in human history. Germany had outdone itself.

Nevertheless I believe that our - indeed my - hatred should come to an end and this has actually happened. It is only temporarily rekindled by discussions like the present one. But the fear, one hopes totally unjustified, persists.

Although Guthy acknowledges "the destruction and suffering inflicted upon other peoples by Germans in this century", he does not seem to be sufficiently aware that the ideas of Nazi ideology were written in the same language that he uses at home. What he euphemistically calls "Nazi ideology" was a German ideology. Far from being an anomaly, it was very much part of Germany: most Nazis were German and most Germans were Nazi.

On 9 November 1989 (the anniversary of Kristallnacht), when the Berlin Wall came down, we saw on live television moderate German leaders bragging about the reunited Germany and how proud (not humble) they were about their new 'Gross-Deutschland'. No word was uttered about why the partition of Germany had taken place 44 years earlier. It will take quite a few generations before the Ridleys and the Meijlers fully trust Germany again.

In itself, Guthy's letter is not a bad one; in principle, he may even be correct. The problem is, that it was written by a German, and that Germany's recent history is too bleak for German intellectuals to face. German history can never be undone or outdone, not even by the histories of the Portuguese, Spanish, British, Dutch and French. I wish that the international scientific community could help its German colleagues with this problem. But it is discouraging if presentday German scientists still seem not to understand the emotions of the victims of their parents.

\section{Interuniversity Cardiology}

Frits L. MEIJLER

Institute of the Netherlands,

Utrecht, The Netherlands

\section{Leukaemia and unemployment}

$\mathrm{S}_{\mathrm{IR}}$ - The causes of cancer are mysterious indeed. There is a remarkable negative correlation $(r=-0.77, P=0)$ between risk of leukaemia and male umemployment by county in England and Wales (see figure). Extrapolating wildly through the data points towards the $x$-axis we see that cancer risk falls to zero when male unemployment reaches 37 per cent. Whatever the basis of this association (presumably some function of economic prosperity) it is clear that Her Majesty's Government has a coherent strategy to tackle the national leukaemia problem. Simon P. WolfF Department of Clinical Pharmacology, UCMSM,

University College London,

5 University Street (Rayne Institute), London WC1E 6JJ, UK

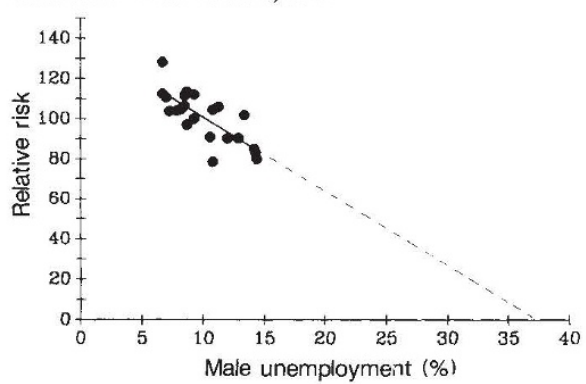

Incidence of leukaemia/lymphoma (age-and sex-standardized relative risks for 22 counties and 14,850 total cases of lymphoproliferative disease in England and Wales collated from 1985 to 1988) versus male unemployment at time of 1981 Census. Data were obtained from (1) Leukaemia and Lymphoma: an Atlas of Distribution within Areas of England and Wales 1984-1988 (R. A. Cartwright, F. E. Alexander, P. A. McKinney, T. J. Rickets, London, Leukaemia Research Fund, 1990 and (2) Office of Population Censuses and Surveys, Census 1981, Key Statistics for Local Authorities, HMSO, 1984.

\section{Gene manipulation}

SIR - I wish to raise an issue of potentially great importance to programmes for the manipulation of human genes.

Conception is a matter of vital importance, and is probably the outcome of several factors evolved in the search for the most suitable offspring. These factors are at present poorly understood. Much more experimental work will be necessary before it will be possible to identify the ethical principles that should govern such work.

But what if our capacity to determine ethical questions - morality in short - is itself linked with our genes?

Only if that surmise is proved wrong could a research venture boast that it had been conducted ethically. This question in my opinion should be widely and openly discussed.

KAJ ÖSTERLUND

Department of Biochemistry.

University of Helsinki,

Unionionkatu 35,

o0170 Helsinki,

Finland

\section{Time of grace}

SIR - As a matter of course, I regularly scan the classified advertisements at the back of Nature in the hope of one day seeing a position that is tailor-made for me. I note, however, that while advertisements from overseas institutions have closing dates generally a month after the publication date, these from institutions in the United Kingdom average two weeks. This means that by the time the issue reaches the libraries in these remote corners of the globe, one generally has less than five days to make an application and get it to the United Kingdom. I'm sure its not a planned conspiracy to make sure researchers currently overseas cannot apply for such positions but wish to suggest a little a little more thought in this regard. Nature has an international readership. SIMON MALPAS

Department of Cardiac Physiology, National Cardiovascular Research Center,

7-1, Fujishiro-dai, 5 chome, Suita City, Osaka 565,

Japan

\section{Lacuna seeker}

SIR - I recently took a 'straw poll' of a class of 83 first-year biology students, to see how many of them had come upon the notion that, even in these banausic times, there is such a thing as the philosophy of science, and that reductionism constitutes one approach by which one may seek to understand nature. To this end I asked them if they had come upon the term 'reductionism'. Not one of them had.

May I invite other academics to carry out a similar exercise? The results might persuade them that knowledge among science undergraduates of even the most basic philosophical ideas constitutes a lacuna which merits removal.

DOUGLAS B. KeLL

Department of Biological Sciences,

University College of Wales,

Aberystwyth, Dyfed SY23 3DA, UK 